\title{
COUROUPITA GUIANENSIS: THE RESERVOIR OF MEDICINAL COMPOUNDS OF HUMAN WELFARE
}

\author{
FAMINA JASMINE S, VINAYAGA MOORTHI P*
}

Department of Human Genetics and Molecular Biology, Bharathiar University, Coimbatore, Tamil Nadu, India. Email: vinayputhu@gmail.com

Received: 14 November 2016, Revised and Accepted: 21 December 2016

\begin{abstract}
Medicinal plants play a role in the traditional form of providing relief to several diseases. Couroupita guianensis is also a type of medicinal plant which has antibacterial, antimycobacterial, antimicrobial, antioxidant, antitumor, antiulcer, antinociceptive, anthelmintic, antifertility, and antifungal activities. The chemical constituent of $C$. guianensis such as indirubin serves as an antibacterial and antifungal agent because it particularly cures fungal diseases. It is active for the treatment of chronic myelocytic leukemia. The extract of isatin from the flower of $C$. guianensis is also a chemical component that has been used as prophylactic agent, prevents free radial-induced cancer, acts as a chemotherapeutic agent to kill cancer cells, and it has antioxidant (act as major defense) and anticancer activities against human promylocytic leukemia 60 cells. The extract of chloroform of fruit of C. guianensis shows good antimicrobial activity but low antimycobacterial activity. The plant extract of $C$. guianensis is equipotent to standard drugs such as paracetamol in its analgesic activity and indomethacin in its anti-inflammatory activity.
\end{abstract}

Keywords: Couroupita quianensis, Antibacterial activity, Anti tumor activity, Antioxidant activity, Anti biofil.

(C) 2017 The Authors. Published by Innovare Academic Sciences Pvt Ltd. This is an open access article under the CC BY license (http://creativecommons. org/licenses/by/4. 0/) DOI: http://dx.doi.org/10.22159/ajpcr.2017.v10i3.16174

\section{INTRODUCTION}

Couroupita guianensis Abul is commonly known as Ayahuma and Cannonball tree. It belongs to the family Lecythidacea having 325 tropical Trees belong to 15 genera. One of the species $C$. guianensis is found in the tropical regions of South America. In Brazil, it is popularly known as macaco cuida, abrico-de macaco, castanha-de-macaco, and amendoados-anoles. In Hindi, it is said to be Kailashpati [1], in Telugu, it is said to be Mallikarjuna flower, and in Tamilnadu, it is said to be Nagalingam flower because the center of the flower resembles Sivalingam shape. It has snake-shaped pollen and very good fragrance [2]. The C. guianensis trees are 90' tall and indigenous to Amazon forest; leaves are up to 6" long, with serrate margin and flowers are Racemes; yellow, reddish, and pink with stunning fragment. Large 3 " to 5" waxy aromatic smelling can be seen on the bark of the trunk (Cauliflory). Fruits are large, globose woody in nature, and look like big rusty cannon balls hanging in cluster and seeds are small, white, and have unpleasant smell with edible jelly. The hard shells are used to make containers and utensils. Medicinal uses of $C$. guianensis, in Chinese medication, constitute antipyretic, antidepressant, analgesic, antiseptic, anti-inflammatory, antiprotozoal, anticancer, and antiulcer activities. In Ayurveda, they are used extensively for its anti-inflammatory property. The flower of C. guianensis comprises antibacterial activity and antifungal property. The tree contains antibiotic, antifungal, antiseptic, and analgesic qualities. C. guianensis was used as an ingredient in many ways for curing gastritis, scabies, bleeding piles, dysentery, and scorpion poison. The various parts of $C$. guianensis such as leaves, flowers, and barks are used to treat hypertension, tumor, pain, and inflammatory reactions. Leaves are used to make juice which is used to treat skin diseases, and South Americans use each part of the C. guianensis tree to treat malaria. The studies of chemical constituents show the presence of $\alpha$-amirin, $\beta$-amirin, $\beta$-sitosterol, nerol, tryptanthrine, indigo, indirubin, isatin, linoleic acid, carotenoids, and sterols [3-8]. Singh et al. [9] reported that aqueous extract of $C$. guianensis is endowed with flavonoids, alkaloids, phlorotannins, glycosides, tannins, steroids, and terpenoids. Isatin is also a chemical constituent of $C$. guianensis that has antioxidant activity, is cytotoxic to human promylocytic leukemia (HL60) cells, and it is used as a prophylactic agent to prevent free radial-induced cancer and as a chemotherapeutic agent to kill cancer cells.

\section{ANTIBACTERIAL ACTIVITY}

Extract of $C$. guianensis has been proved to have an excellent antibacterial activity. Ethyl alcohol extract of fruit (pulp) of C. guianensis has reported to have an excellent antibacterial activity against Gram-positive (Staphylococcus aureus and Bacillus subtilis) and Gram-negative (Escherichia coli and Pseudomonas aeruginosa) bacteria [2]. Similarly, chloroform extract of fruit of $C$. guianensis tested using disc diffusion method has found to be active against Gram-positive and Gram-negative bacteria. In this, the chloroform extract of $C$. guianensis exhibited 26 and $20 \mathrm{~mm}$ of zone of inhibition (ZOI), respectively, against $S$. aureus and Shigella flexneri. In case of clinical isolates, E. coli (ESBL-3984) was highly susceptible to chloroform extract of $C$. guianensis with $20 \mathrm{~mm}$ ZOI. The ZOI of other isolates was ESBL-3904 (18 mm), ESBL-3971 (14 mm), ESBL-75799 (16 mm), ESBL-3894 (15 mm), ESBL-3967 (12 mm), and MRSA (18 mm) [10]. Similarly, Singh et al. [9] reported the susceptibility of Gram-positive bacteria against chloroform extract of $C$. guianensis compared to Gram-negative bacteria. The minimum inhibitory concentrations (MICs) of ethanol, methanol, and chloroform extracts of C. guianensis were 25,50 , and $100 \mathrm{mg} \mathrm{ml}^{-1}$, respectively [9]. Antibacterial activity of plant extract of $C$. guianensis was observed in two different solvents, namely dichloromethane and acetone. The acetone extract of C. guianensis showed $25 \mathrm{~mm}$ ZOI against Staphylococcus sp., whereas in dichloromethane extract, it was $28 \mathrm{~mm}$. The bioactive compound of C. guianensis that possesses antibacterial activity was also assessed. Indirubin was used as an antibacterial agent. In particular, it was effective against fungal diseases such as dermatophytic and skin lesion diseases [2]. Al-Dhabi et al. [9] reported that chloroform extract of fruit C. guianensis has a sensible antimicrobial activity at 0 to $26 \mathrm{~mm}$ of ZOI. Methanol and aqueous leaf extracts of C. guianensis were screened against six bacteria and four fungal pathogens to check for antifungal activities. The methanol extract of $C$. guianensis showed ZOI between 31-12 $\mathrm{mm}$ and 19-8 mm against bacteria and fungi, respectively [11]. Antimicrobial activity against Gram-positive bacteria such as $S$. aureus showed $11 \mathrm{~mm}$ of ZOI and antimicrobial activity against Gram-negative bacteria such as coli showed $16 \mathrm{~mm}$ of ZOI, P. aeruginosa showed $15 \mathrm{~mm}$ of ZOI, and Klebsiella. These antimicrobial activities were compared in the review [12]. The Dichloromethan and acetone extract of C. quianensis showed 25 and $28 \mathrm{~mm}$ ZOI against S. aureus. with ZOI 
of 25 and $28 \mathrm{~mm}$, respectively, and the compound responsible for this antibacterial activity was also partially purified. Shah et al. [14] have also recorded the antibacterial activity of ethanol extract of pulp of $C$. guianensis and found susceptibility of $B$. subtilis $(18 \mathrm{~mm})$ compared to S. aureus $(13 \mathrm{~mm})$ and E. coli $(12 \mathrm{~mm})$. A similar study was also done by Azimi et al. [15]. Regina et al. [16] Reported the antibacterial property of solvent extracts of fruit rind of $C$. guianensis. Similarly, Ramalakshmi et al. [17] reported the similar kind of activity in methanolic extract of fruit of $C$. guianensis.

\section{ANTIBIOFILM PROPERTY OF C. GUIANENSIS}

Biofilm-associated diseases are caused by Gram-positive bacteria including caries, gingivitis, peritonitis, endocarditis, and prostatitis. Indirubin is one of the important chemical components of $C$. guianensis which is used as an antifungal agent, particularly to cure fungal diseases, dermatophytic and skin lesion diseases. It is active for the treatment of chronic myelocytic leukemia. It suppresses the autophosphorylation of fibroblast growth factor receptor-1 but stimulates extracellular signal and regulates kinase (ERK1/2) activity through P38 mitogen-activated protein kinase. An inhibition of biofilm formation was obtained at low concentrations with $52 \%$ inhibition [23].

\section{ANTIMYCOBACTERIAL ACTIVITY}

The chloroform extract of fruit of $C$. guianensis was tested against M. tuberculosis H37RV and rifampicin. The MIC was determined using microdilution assay. This was performed in sterile MiddleBrook 7H9 broth supplemented with $10 \%$ albumin-dextrose-catalase. The plates were incubated at $37^{\circ} \mathrm{C}$ under $5 \% \mathrm{CO}_{2}$ for 2 weeks [2]. Chloroform extract of $C$.guianensis has antimycobacterial activity at 0 to $26 \mathrm{~mm}$ ofZOI and it is effective against Plesiomonas shigelloides, Cocci aureus, Vibrio mimicus, and Proteus vulgaris and there was a moderate activity against E. coli, Klebsiella pneumonia, and Salmonella typhi [10]. Chloroform, hexaneane, and ethanol extracts of fruit of $C$. guianensis showed vital antibacterial $(10 \mathrm{mg} / \mathrm{ml})$ and antifungal activities $(10 \mathrm{mg} / \mathrm{ml})$. The concentration $(10 \mathrm{mg} / \mathrm{ml})$ during fermentation of ethanol extract showed sensible restrictive activity against Candida albicans [16]. In fungi, the chloroform extract of $C$. guianensis shows moderate activity against C. albicans $(18 \mathrm{~mm})$ and Malassezia pachydermatis shows $16 \mathrm{~mm}$ of ZOI. C. albicans, which causes candidacies, is an opportunistic pathogen, mostly found in patients with AIDS [10].

\section{WOUND-HEALING PROPERTY}

Ethanol extract from whole plant (barks, leaves, flowers, and fruit) of $C$. guianensis hurries wound healing by increasing the enduringness [24]. Umachigi et al. [24] reported that the wound-healing activity in ethanolic extract of whole plant of $C$. guianensis accelerates wound healing by decreasing the surface area of wound and increasing the tensile strength [11].

\section{ANTIOXIDANT ACTIVITY}

Bafna et al. [25] reported the property of antioxidant present in the ethyl acetate fraction of C. guianensis. Extracts of $C$. guianensis (flower) have antioxidant and antitumor activities [26].

\section{ANTITUMOR ACTIVITY}

Cytotoxicity against HL60 cells was determined by (3-(4, 5-dimethylthiazol-2-yl)-2,5-diphenyltetrazolium bromide assay. Isatin is a vital compound present in C. guianensis that shows solid inhibitory activity with $\mathrm{Ec}_{50}$ worth of $72.80 \mu \mathrm{g} / \mathrm{ml}$ and HL60 cells in a dose-dependent manner by CC $_{50}$ worth of $2.94 \mu \mathrm{g} / \mathrm{ml}$ which lead eventually to caspase-mediated cell death confirmed by fluorescence-activated cell sorting analysis (Sundarajan and Koduru, 2014). The flower of $C$. guianensis consists of isatin compound that has cytotoxicity against human carcinoma cell lines. It has the potential to be used as a chemotherapeutic agent against cancer. Isatin isolated from floral parts exhibited cytotoxicity against HL60 cells [11]. Prabhu and Ravi [27] found that the methanolic extract of flower of $C$. guianensis showed an excellent anticancer activity against HeLa (202.6 $\mu \mathrm{g} / \mathrm{mL})$, NIH3T3 $(280 \mu \mathrm{g} / \mathrm{mL})$, and HepG2 (470.8 $\mu \mathrm{g}$ / $\mathrm{mL}$ ). Prabhu and Ravi [27] extracted stigmasterol and quercetin from methanol leaf extract of $C$. guianensis and quantified as 242.14 and $188.97 \mu \mathrm{g} / \mathrm{ml}^{-1}$, respectively.

\section{ANTIULCER ACTIVITY}

Ethanolic extract of leaves of $C$. guianensis shows an excellent antiulcer activity [28]. Ethanolic extract of C. guianensis $(150 \mathrm{mg} / \mathrm{kg}$ and $300 \mathrm{mg} / \mathrm{kg}$ ) has the ability to inhibit the leukocyte migration into peritoneal cavity after the carrageenan injection. Almost a dose of $100 \mathrm{mg} / \mathrm{kg}$ abolishes the cell migration. C. guianensis fractions have anti-inflammatory effect. Hence, they exhibit reduction on cell migration and inhibit cytokine and inflammatory mediator production [2]. Hence, there is gastric lesion formation due to gastric blood flow which contributes to the development of hemorrhage and narcotic aspects of tissue injury [11].

\section{ANTINOCICEPTIVE ACTIVITY}

Pinheiro et al. reported that ethanol extract of $C$. guianensis leaves exhibited antinociceptive activity [29], by three analgesic models (acetic acid-induced contortions, tail flick, and hot plate). CEE (crude ethanol extract) and fractions inhibited the number of contortions induced by acetic acid.

\section{ANTHELMINTIC ACTIVITY}

Chloroform, acetone, and ethanolic extracts of $C$. guianensis flower have good anthelmintic activity. However, the alcohol extracts are more effective than chloroform and acetone extracts. This activity was compared with the standard drug Piperazine citrate [2].

\section{ANTIFERTILITY ACTIVITY}

Benzene, ethyl alcohol, and water extracts of bark and flower of C. guianensis showed antifertility activity in assorted stages of estrus cycle in female rats [30]. Ethyl alcohol extract of flower of $C$. guianensis supports the quantity of implantations [2].

\section{ANTIFUNGAL ACTIVITY}

Despax et al. [31] proposed that granules formed cell along with serious structural and morphological damage on cellular membranes when fungi were treated with AgNPs granules composed of Ag, sulfur, phosphorous, and nitrogen on cellular walls and in the cytoplasm of yeast, with increased concentration of cellular walls. Ionic silver released from silver nanoparticles inhibits the respiratory enzymes that can induce oxidative stress upon the generation of reactive oxygen species [32].

\section{PRECURSOR FOR NANOPARTICLE SYNTHESIS}

Presence of highly active bioactive compounds paved the way for using $C$. guianensis as a precursor for the synthesis of various types of metal and other nanoparticles. Subramaniam et al. [33] have used flowers of $C$. guianensis for the synthesis of gold nanoparticles (AUNps) and reported the larvicidal property against Anopheles stephensi. Antiplasmodial activity of the AUNps synthesized from C. guianensis was also recorded by Subramaniam et al. [33]. Similarly, Vimala et al. [34] have used leaf and fruit extracts for the synthesis of silver nanoparticles (AgNps). In this, they observed an excellent larvicidal activity against Aedes aegypti with $\mathrm{LC}_{50}$ value of 2.1 and $2.09 \mathrm{ppm}$ with respect to leaf and fruit extract-synthesized AgNps. Sathishkumar et al. [35] also used fruit extract of $C$. guianensis for the synthesis of AUNps and revealed its antioxidant activity. Kumar et al. [36] have used have used flower buds of $C$. guianensis for the synthesis of AgNps and reported their excellent antibacterial activity against Micrococcus luteus and B. subtilis with ZOI of 24 and $23 \mathrm{~mm}$, respectively. 


\section{CONCLUSIONS}

From this study, it can be concluded that $C$. guianensis has many medicinal values and has various homeostatic, antipyretic, antiinflammatory, and sedative properties in the treatment of bacterial and viral infection. Thus, the plant can be further explored for its phytochemical profile to identify the active constituents responsible for the above-mentioned activities.

\section{REFERENCES}

1. Satyavati GV, Raina MK. Medicinal Plants of India. Vol. 1. New Delhi: Indian Council of Medical Research. p. 286.

2. Sundarajan R, Koduru R. A complete profile of Couroupita guianensistraditional uses pharmacological activities and phytoconstituents. Pharmacophore 2014:5(1):147-59.

3. Wong KC, Tie DY. Volatile constituents of Couroupita guianensis Aubl. Flowers. J Essent Oil Res 1995;7:225-7.

4. Rane JB, Vahanwala SJ, Golatkar SG, Ambaye RY, Khadse BG. Chemical examination of the flowers of couroupita guianensis Aubl. Indian J Pharm Sci 2001;63:72-3.

5. Bergman J, Lindstrom JO, Tilstam U. The structure and properties of some indolic constituents in Couroupita guianensis Aubl. Tetrahedron $1985 ; 41: 2879-81$

6. Sen AK, Mahato SB, Dutta NL, Couroupitine A. A new alkaloid from couroupita guianensis. Tetrahedron Lett 1974;7:609-10.

7. Row LR, Santry CS, Suryananayana PP. Chemical examination of couroupita guianensis. Curr Sci 1966;35(6):146-7.

8. Anjaneyulu AS, Rao SS. A new ketosteroid from the bark of Couroupita guianensis Aubl. Indian J Chem B Org Chem 1998;37(9-12):382-6.

9. Al-Dhabi NA, Balachandran C, Raj MK, Duraipandian V, Muthukumar C, Ignacimuthu S, et al. Antimicrobial, antimycobacterial and antibiofilm properties of Couroupita guianensis Abul. Fruit extract. BMC Complement Altern Med 2012;12:242.

10. Singh R, Kumari N, Gangwar M, Nath G. Qualitative characterization of phytochemicals and in vitro antimicrobial evaluation of leaf extract of Couroupita guianensis Aubl. - A threatened medicinal tree. Int J Pharm Pharm Sci 2015;7(7):212-5.

11. Gousia SK, Kumar KA, Kumar TV, Latha JN. Biological activities and medicinal properties of Couroupita guianensis. Int J Pharm Pharm Sci Res 2013;3(4):140-3.

12. Kumar CS, Naresh G, Sudheer V, Veldi N, Elumalai A. A short review on therapeutic uses of Couroupita guianensis Aubl. Int Res J Pharm Appl Sci 2011;1(1):105-8.

13. Sivakumar T, Shankar T, Vijayabaskar P, Geetha G. Efficacy of Couroupita guianensis against selected human pathogens. Adv Biol Res 2012;6(2):59-63.

14. Shah GN, Shete SA, Patil SA, Patil KD, Killedar SG. Standardization and antibacterial activity of Couroupita guianensis fruit pulp extract. Int J Pharm Phytochem Res 2012;4(4):185-9.

15. Azimi H, Fallah-Tafti M, Khakshur AA, Abdollahi M. A review of phytotherapy of acne vulgaris: Perspective of new pharmacological treatments. Fitoterapia 2012;83(8):1306-17.

16. Regina V, Rajan KM. Phytochemical analysis, antioxidant and antimicrobial studies of fruit rind of Couroupita guianensis. Int J Curr Sci 2012;221:262-7.

17. Ramalakshmi C, Ranjitsingh AJ, Kalirajan K, Kalirajan A, Athinarayanan G, Mariselvam R. A preliminary screening of the medicinal plant Couroupita guianensis for its antimicrobial potential against clinical and fish-borne pathogens. Elixir Appl Biol 2013;57:14055-7.

18. Hoessel R, Leclerc S, Endicott JA, Nobel ME, Lawrie A, Tunnah P, et al. Indirubin, the active constituent of a Chinese antileukaemia medicine, inhibits cyclin-dependent kinases. Nat Cell Biol 1999;1(1):60-7.

19. Leclerc S, Garnier M, Hoessel R, Marko D, Bibb JA, Snyder GL, et al. Indirubins inhibit glycogen synthase kinase-3 beta and CDK5/ p25, two protein kinases involved in abnormal tau phosphorylation in
Alzheimer's disease. A property common to most cyclin-dependent kinase inhibitors? J Biol Chem 2001;276(1):251-60.

20. Perabo FG, Landwehrs G, Frössler C, Schmidt DH, Mueller SC. Antiproliferative and apoptosis inducing effects of indirubin-30monoxime in renal cell cancer cells. Urol Oncol 2009;29(6):815-20.

21. Perabo FG, Frössler C, Landwehrs G, Schmidt DH, von Rücker A, Wirger A. Indirubin-30-monoxime, a CDK inhibitor induces growth inhibition and apoptosis-independent up-regulation of survivin in transitional cell cancer. Anticancer Res 2006,26:2129-35.

22. Marko D, Schätzle S, Friedel A, Genzlinger A, Zankl H, Meijer L. Inhibition of cyclin-dependent kinase 1 (CDK1) by indirubin analogs in human tumour cells. Br J Cancer 2001;84(2):283-9.

23. Zhen Y, Sørensen V, Jin Y, Suo Z, Wiedlocha A. Indirubin-3'-monoxime inhibits autophosphorylation of FGFR 1 and stimulates ERK1/2 activity via p38 MAPK. Oncogene 2007;26(44):6372-85.

24. Umachigi SP, Jayaveera KN, Ashok KC, Kumar GS. Antimicrobial, wound healing and antioxidant potential of Couroupita guianensis in rats. Pharm Online 2007;3:269-81.

25. Bafna AR, Mishra SH, Deoda RS, Bafna PA, Kale RH. In vitro antioxidant activity of ethyl acetate fraction of water extract of flowers of Couroupita guianensis. Int J Pharm Pharm Sci 2011;3(4):4-6.

26. Premanathan M, Radhakrishnan S, Kulangiappar K, Singaravelu G, Thirumalaiarasu V, Sivakumar T, et al. Antioxidant \& anticancer activities of isatin (1H-indole-2,3-dione), isolated from the flowers of Couroupita guianensis Aubl. Indian J Med Res 2012;136(5):822-6.

27. Prabhu V, Ravi S. Quantification of quercetin and stigmasterol of Couroupita guianensis AUBL by HPTLC method and in vitro cytotoxic activity by MTT assay of the methanol extract against HeLa, NIH3T3 and HepG2 cancer cell lines. Int J Pharm Pharm Sci 2012;4(4):126-30.

28. Elumalai A, Eswaraiah MC, Didala A. Investigations on antioxidant, an antiarthritic and antiplatelet study in Couroupita guianensis aubl leaves by in vitro methods. 2012;3(3):2262-9.

29. Pinheiro MM, Fernandes SB, Fingolo CE, Boylan F, Fernandes PD. Anti-inflammatory activity of ethanol extract and fractions from Couroupita guianensis Aublet leaves. J Ethnopharmacol 2013;146(1):324-30.

30. Geetha M, Saluja AK, Shankar MB, Mehta RS. Analgesic and anti-inflammatory activity of Couroupita guianensis Aubl. J Nat Remedies 2004;4(1):52-5.

31. Despax B, Saulou C, Raynaud P, Datas L, Mercier-Bonin M. Transmission electron microscopy for elucidating the impact of silver versus nanosilver- containing coating on the model yeast Saccharomyces cerevisiae. Nanotechnology 2011;22(17):175101.

32. Rajarathinam M, Girilal M, Peter M, Kalaichelvan PT. Augmentation potential antifungal activity of Gandhaka rasayanam (a Siddha compound) using green synthesized silver nanoparticles from Couroupita guianensis leaf extract against selected pathogenic strain. Int Res J Pharm 2013;4(6):234

33. Subramaniam J, Murugan K, Panneerselvam C, Kovendan K, Madhiyazhagan P, Dinesh D, et al. Multipurpose effectiveness of Couroupita guianensis-synthesized gold nanoparticles: High antiplasmodial potential, field efficacy against malaria vectors and synergy with Aplocheilus lineatus predators. Environ Sci Pollut Res Int 2016;23(8):7543-58.

34. Vimala RT, Sathishkumar G, Sivaramakrishnan S. Optimization of reaction conditions to fabricate nano-silver using Couroupita guianensis Aubl. (Leaf \& fruit) and its enhanced larvicidal effect. Spectrochim Acta A Mol Biomol Spectrosc 2015;135:110-5.

35. Sathishkumar G, Pradeep KJ, Vignesh V, Rajkuberan C, Jeyaraj M, Selvakumar M. Cannonball fruit (Couroupita guianensis, Aubl.) Extract mediated synthesis of gold nanoparticles and evaluation of its antioxidant activity. J Mol Liq 2016;215:229-36.

36. Kumar TV, Murthy JS, Rao MN, Bhargava Y. Evaluation of silver nanoparticles synthetic potential of Couroupita guianensis Aubl., Flower buds extract and their synergistic antibacterial activity. 3 Biotech 2016;6(1):92. 